\title{
Partial Budgeting of floor bedding to improve poultry health in Western Java
}

\author{
Dikky Indrawan \\ School of Business \\ IPB University \\ Bogor, Indonesia \\ rdikky@apps.ipb.ac.id
}

\author{
Asep Rakhmat \\ Centre for Tropical Animal Studies, \\ IPB University \\ Bogor, Indonesia \\ asepr40@gmail.com
}

\begin{abstract}
Poultry litter is a habitat for microbe's growth included various chicken gastrointestinal pathogens. Litter also absorb several compounds or gasses from outside of the poultry house that affects poultry health. Many studies found that the composted manure had more soil fertility which consists of many organic components. Thus, more complete nutrients and other growth factors in manure were found higher than chemical fertilizers (inorganic). It is suggested that the application of floor beddingcould improve poultry health and increase income from manure. The objective of this study was to measure the costof several types of floor bedding in poultry sheds. The partial budget was employed based on the literature study.The cost of the application and its related income were calculated. The calculation was modeled based on the poultry sheds then the poultry house. The study foundthat the partial budget analysis identified the findings lead to a strongly positive incentive for farmers to apply of floor bedding in their poultry farms. The incentive may drivepoultry farmers in West Java to pay attention to invest decent sheds to improve poultry health.
\end{abstract}

Keywords-poultry, floor bedding, partial budgeting, gastrointestinal pathogens

\section{INTRODUCTION}

Poultry litter is a valuable by-product but at the same time potentially influence poultry health and production growth in commercial farms. Since poultry litter is a habitat for microbes' growth included various chicken gastrointestinal pathogens. Litter also absorb several compounds or gasses from outside of the poultry house that affects poultry health. Estimated everyday litter produced by a broiler and laying hen are $0.09 \mathrm{~kg}$ and 0.18 $\mathrm{kg}$, respectively[1]. When reared in suboptimal conditions, broilers may show respiratory problems and locomotion problems[2].

Bedding material is one of many factors that affect the composition of litter/manure [3, 4]. Several studies explore experimental attempts at replacing the traditional litter material to increase poultry health and productivity in the food industry[2, 5]. Studieson the composted manure found more soil fertility which consists of many organic components[5]. Consequently, the manure had more complete nutrients and other growth factors compared to chemical fertilizers (inorganic)[6]. It is suggested that the application of floor beddingcould improve poultry health and increase income from manure.
In poultry, many alternative bedding materials used in the poultry industry, for instances wood, papers, dry straw, rice hulls, and other possible materials. As poultry bedding is widely used and the yearly cost of animal bedding is increasing. Therefore, choosing the right bedding material in association with poultry production and economic performance becomes more complicated. Thus, it is important to evaluate floor bedding material impact on poultry health, poultry production, and economic performance[7]

Identifying suitable and affordable bedding material is important in poultry production in developing countries, as it makes a significant contribution to the farmers' business[6]. This study sought after to evaluate how alternative poultry bedding materials used separately or in combination affected poultry production in association with a different type of business and its economic performance. Therefore, the objective of this study was to measure the cost of several types of floor bedding in poultry sheds.

\section{MATERIALS AND METHODS}

Six different litter materials were evaluated namely rice husk, sawdust, rice husk mixed with sawdust, rice husk mixed with silica, wood shavings, and rice straw. Experimental information related to these floor beddings impact on animal health and production efficiency was collected from the literature study.

The study employed partial budgetingto evaluate these floor bedding alternatives based on theinformation provided by secondary data[8,9].We evaluated activity that changed and its financial impact on farmers cost and income. We simulated to cost and revenue of the different types of floor bedding in three types of a poultry farm business, such as company, makloon and independent based on Western Java situation in 2019. Company is a large commercial farm, makloon farm is farmers that reared poultry based on fee, and an independent farm is small-medium commercial farms. The partial budget models were developed as follows:

1. The model was developed based on the combination of six types of floor bedding and three types of a poultry farm business.

2. The calculation was modeled based on the poultry sheds then the poultry house. 
3. Input variable was based on the experimental data

4. The cost of the application and its related income were calculated.

5. The effect of health and production was measured and compared for one production cycle.

6. The mean cost and revenue for each farm business were calculated based on each type of floor bedding.

7. The cost and revenue were compared to examine added cost and revenue and/or cost and revenue reduction.

\section{RESULTS}

The study found that the top two floor beddings were from mixed rice husk. The floor bedding from rice husk mixed with silica came up as the first (Table 1). Floor bedding from risk husk mixed with sawdust came close as the second best. These two floor-beddings gave the highest productivity, the lowest unhealthy poultry and the lowest mortality rate for all types of farm business compare to other types of floor beddings. Whereas, floor bedding that made from wood shaving was the worst in productivity, had the highest unhealthy poultry and the highest mortality rate among these alternatives floor bedding for poultry production.

The results of the productivity, the unhealthy poultry and the mortality rate of floor bedding applications were found to have a different impact on the poultry performance. In the farm business simulation, each performance of the alternative floor bedding was found to give different impact on cost reduction and revenue improvement for each type of farm business. The following paragraphs and tables are explaining the difference.

When comparing the partial bedding simulation of floor bedding in the company type of farm business (Table 2). We found that the rice husk mixed with silica was the floor bedding material that gave the most cost reduction compared to other materials (rice husk used as the comparison baseline). This material performed better than other materials. The material could reduce the cost of workers, feed, and heating. Moreover, the material increased the revenue and farm profit since it could increase productivity. On the contrary, sawdust gave the worst performance in cost reduction, revenue improvement and farm profit compare to other materials.

Almost similar performance was found in the partial bedding simulation of floor bedding in the makloon type of farm business (Table 3). The rice husk mixed with silica was found as well as the floor bedding material that gave the most cost reduction compared to other materials (rice husk used as the comparison baseline). The heating cost, medicine, vaccines and vitamins, and rope were reduced by the usage of rice husk mixed with silica. Also, revenue and farm profit were increased by poultry productivity. Differently, in makloon business, we found that rice husk mixed with sawdust gave the worst performance in cost reduction, revenue improvement and farm profit compare to other materials.
In the independent type of farm business, all floor bedding materials came up worst that the regular usage of rice husk (Table 4). The rice husk was found as the floor bedding material that gave a better profit compared to other materials (rice husk used as the comparison baseline). While rice straw usage as the floor bedding gave the most cost reduction compared to other materials, this material also gave the lowest revenue and farm profit.

\section{DISCUSSION}

The findings show the alternative floor bedding material usage provides the possibility to reduce the health problem and mortality rate. Even though the usage floor bedding could not drastically reduce the problems, there was an incentive for farmers to apply floor bedding in two types of a farm business, namely company and makloon. We suspected that the efforts to reduce health and mortality problem in independent farms may be caused by the limited knowledge and discipline in performing the application of litter procedures.

In this study, we found that the cost reduction and the revenue improvement were possible to achieve by the application of floor bedding materials. In the different type of business, the impact on the cost of the application of floor bedding was found in a different activity. In company and makloon farms, the rice husk mixed with silica bedding application could reduce the cost and increased the revenue. Therefore, the application of floor bedding especially the rice husk mixed with silica bedding gives the benefit for farmers. This resultgives an incentive to motivate farmers to applied the rice husk mixed with silica bedding voluntarily.

These findings prove that the benefit of using floor bedding leads to a positive incentive for farmers to apply floor bedding. This incentive may motivate poultry farmers in a different type of business in Western Java. Furthermore, the farmers could start to pay attention to invest in decent material for bedding and sheds to improve poultry health.

\section{CONCLUSION}

The study found that the application of different type of floor bedding in poultry farms reduced the farm cost and increased the farm revenue in the company and makloon farms. The usage of rice husk mixed with silica gave the best performance. Consequently, the application of rice husk mixed with silica as a floor bedding confirmed an economic impact gives an incentive for the farm business. However, the usage of alternative floor bedding in the independent farm gave unexpected results. This may be caused by farmers' knowledge, and behavior.

\section{REFERENCES}

[1] J. Tao and K. Mancl, "Estimating manure production, storage size, and land application area," Agriculture and Natural Resources Fact Sheet, 2008.

[2] I. Almeida Paz et al., "Selecting appropriate bedding to reduce locomotion problems in broilers," Brazilian Journal of Poultry Science, vol. 12, no. 3, pp. 189-195, 2010. 
[3] C. W. Ritz and W. C. Merka, "Maximizing poultry manure use through nutrient management planning," 2009.

[4] K. Benabdeljelil and A. Ayachi, "Evaluation of alternative litter materials for poultry," Journal of Applied Poultry Research, vol. 5, no. 3, pp. 203-209, 1996.

[5] A. Garcês, S. Afonso, A. Chilundo, and C. Jairoce, "Evaluation of different litter materials for broiler production in a hot and humid environment: 1 . Litter characteristics and quality," Journal of Applied Poultry Research, vol. 22, no. 2, pp. 168-176, 2013

[6] M. Munir, C. Belloncle, M. Irle, and M. Federighi, "Woodbased litter in poultry production: a review," World's Poultry Science Journal, vol. 75, no. 1, pp. 5-16, 2019
[7] P. Jones, J. Niemi, J.-P. Christensen, R. Tranter, and R. Bennett, "A review of the financial impact of production diseases in poultry production systems," Animal Production Science, vol. 59, no. 9, pp. 1585-1597, 2019.

[8] K. Huijps, H. Hogeveen, T. J. Lam, and A. O. Lansink, "Costs and efficacy of management measures to improve udder health on Dutch dairy farms," Journal of dairy science, vol. 93, no. 1, pp. 115-124, 2010.

[9] J. Swinkels, H. Hogeveen, and R. Zadoks, "A partial budget model to estimate economic benefits of lactational treatment of subclinical Staphylococcus aureus mastitis," Journal of dairy science, vol. 88, no. 12, pp. 4273-4287, 2005.

\section{APPENDIX}

TABLE 1. COMPARISON OF FLOOR BEDDING IMPACT IN THE DIFFERENT TYPE OF POULTRY BUSINESS IN WESTERN JAVA

\begin{tabular}{|c|c|c|c|}
\hline Floor Bedding & Company & Makloon & Independent \\
\hline \multicolumn{4}{|l|}{ Rice husk } \\
\hline Harvest (\%) & $93.00 \%$ & $92.90 \%$ & $93.00 \%$ \\
\hline Unhealthy (suspected) & $10.00 \%$ & $10.10 \%$ & $10.00 \%$ \\
\hline Mortality & $7.00 \%$ & $7.10 \%$ & $7.00 \%$ \\
\hline \multicolumn{4}{|l|}{ Sawdust } \\
\hline Production $(\mathrm{kg})$ & $93.62 \%$ & $93.85 \%$ & $93.92 \%$ \\
\hline Unhealthy (suspected) & $8.88 \%$ & $8.65 \%$ & $8.58 \%$ \\
\hline Mortality & $6.38 \%$ & $6.15 \%$ & $6.08 \%$ \\
\hline \multicolumn{4}{|l|}{ Rice husk mixed with Sawdust } \\
\hline Harvest (\%) & $94.45 \%$ & $93.21 \%$ & $93.45 \%$ \\
\hline Unhealthy (suspected) & $7.85 \%$ & $9.09 \%$ & $8.85 \%$ \\
\hline Mortality & $5.55 \%$ & $6.79 \%$ & $6.55 \%$ \\
\hline \multicolumn{4}{|l|}{ Rice husk mixed with Silica } \\
\hline Production $(\mathrm{kg})$ & $94.53 \%$ & $94.15 \%$ & $93.37 \%$ \\
\hline Unhealthy (suspected) & $7.57 \%$ & $7.95 \%$ & $8.73 \%$ \\
\hline Mortality & $5.47 \%$ & $5.85 \%$ & $6.63 \%$ \\
\hline \multicolumn{4}{|l|}{ Wood shavings } \\
\hline Harvest (\%) & $92.97 \%$ & $92.34 \%$ & $92.10 \%$ \\
\hline Unhealthy (suspected) & $10.23 \%$ & $10.86 \%$ & $11.10 \%$ \\
\hline Mortality & $7.03 \%$ & $7.66 \%$ & $7.90 \%$ \\
\hline \multicolumn{4}{|l|}{ Rice straw } \\
\hline Harvest (\%) & $93.08 \%$ & $92.50 \%$ & $92.02 \%$ \\
\hline Unhealthy (suspected) & $9.82 \%$ & $10.41 \%$ & $10.88 \%$ \\
\hline Mortality & $6.92 \%$ & $7.51 \%$ & $7.98 \%$ \\
\hline
\end{tabular}

Table 2. Cost And Benefit Comparison Of Floor Bedding Application In The Company Type Of Poultry Business In Western

\begin{tabular}{|l|c|c|c|c|c|}
\hline \multicolumn{1}{|c|}{ Descriptions } & Saw-dust & $\begin{array}{c}\text { Rice husk mixed } \\
\text { with Saw-dust }\end{array}$ & $\begin{array}{c}\text { Rice husk mixed } \\
\text { with Silica }\end{array}$ & Wood shavings & Rice straw \\
\hline Cost & & & & & \\
\hline - Workers & - & - & $(0.17)$ & - & - \\
\hline - DOC & - & - & - & - & - \\
\hline - Feed & - & - & $(0.01)$ & - & - \\
\hline - Litter & 0.33 & 0.11 & 0.25 & 0.11 & 0.22 \\
\hline - Heating & 0.10 & $(0.02)$ & $(0.02)$ & $(0.02)$ & $(0.02)$ \\
\hline - Medicine Vaccines and vitamins & - & - & - & - & - \\
\hline - Disinfectant & - & - & - & - & - \\
\hline - Rope & - & - & - & - & 7.33 \\
\hline Total Cost & 0.00 & 0.00 & $(0.01)$ & 0.00 & 0.00 \\
\hline Revenue & $(0.01)$ & 0.00 & 0.01 & 0.01 & $(0.00)$ \\
\hline Profit & $(0.11)$ & 0.01 & 0.09 & 0.05 & $(0.02)$ \\
\hline
\end{tabular}

Note: Positive sign means higher than the baseline. Negative sign means lower than the baseline. 
Table 3. Cost And Benefit Comparison Of Floor Bedding Application In The Makloon Type Of Poultry Business In Western

\begin{tabular}{|l|c|c|c|c|c|}
\multicolumn{1}{|c|}{ Descriptions } & Saw-dust & $\begin{array}{c}\text { Rice husk mixed } \\
\text { with Sawdust }\end{array}$ & $\begin{array}{c}\text { Rice husk mixed with } \\
\text { Silica }\end{array}$ & Wood shavings & Rice straw \\
\hline Cost & & & & & \\
\hline - Workers & - & - & - & - & - \\
\hline - DOC & - & - & - & - & - \\
\hline - Feed & - & - & 0.25 & - & - \\
\hline - Litter & 0.33 & 0.11 & $(0.02)$ & $(0.02)$ & $(0.02)$ \\
\hline - Heating & - & $(0.02)$ & $(0.60)$ & $(0.20)$ & $(0.20)$ \\
\hline - Medicine Vaccines and vitamins & $(0.20)$ & $(0.20)$ & 0.05 & 0.05 & 0.05 \\
\hline - Disinfectant & 0.05 & 0.05 & $(0.17)$ & $(0.17)$ & $(0.17)$ \\
\hline - Rope & $(0.17)$ & $(0.17)$ & $(0.00)$ & 0.00 & 0.00 \\
\hline Total Cost & 0.00 & 0.00 & 0.02 & $(0.00)$ & $(0.01)$ \\
\hline Revenue & 0.01 & $(0.00)$ & 0.12 & $(0.02)$ & $(0.10)$ \\
\hline Profit & 0.05 & $(0.03)$ & & & \\
\hline
\end{tabular}

Note: Positive sign means higher than the baseline. Negative sign means lower than the baseline.

Table 4. Cost And Benefit Comparison Of Floor Bedding Application In The IndePendent Type Of Poultry Business In WESTERN JAVA (RICE HUSK As A BASELINE)

\begin{tabular}{|c|c|c|c|c|c|}
\hline Descriptions & Saw-dust & $\begin{array}{c}\text { Rice husk } \\
\text { mixed with } \\
\text { Sawdust }\end{array}$ & $\begin{array}{l}\text { Rice husk mixed } \\
\text { with Silica }\end{array}$ & Wood shavings & Rice straw \\
\hline \multicolumn{6}{|l|}{ Cost } \\
\hline - Workers & - & - & - & - & $(0.33)$ \\
\hline - $\mathrm{DOC}$ & - & - & - & - & - \\
\hline - Feed & - & - & - & - & - \\
\hline - Litter & 0.33 & 0.21 & 0.26 & 0.12 & 0.23 \\
\hline - Heating & $(0.03)$ & $(0.18)$ & $(0.18)$ & $(0.18)$ & $(0.18)$ \\
\hline - Medicine, Vaccines and vitamins & - & - & - & - & - \\
\hline - Disinfectant & - & - & - & - & - \\
\hline - Rope & 0.11 & 0.11 & 0.11 & 0.11 & 0.11 \\
\hline Total Cost & 0.00 & 0.00 & 0.00 & 0.00 & $(0.00)$ \\
\hline Revenue & $(0.02)$ & $(0.01)$ & $(0.01)$ & $(0.02)$ & $(0.03)$ \\
\hline Profit & $(0.10)$ & $(0.04)$ & $(0.05)$ & $(0.10)$ & $(0.19)$ \\
\hline
\end{tabular}

Note: Positive sign means higher than the baseline. Negative sign means lower than the baseline. 